OPEN ACCESS

Edited by:

Magdalene K. Montgomery,

The University of Melbourne, Australia

Reviewed by:

Christelle Le Foll,

University of Zurich, Switzerland

Wen Fu,

University of Alberta, Canada

${ }^{*}$ Correspondence:

Jonatan I. Bagger

Jonatan.ising.bagger@regionh.dk

Specialty section:

This article was submitted to

Obesity,

a section of the journa

Frontiers in Endocrinology

Received: 14 October 2020 Accepted: 23 November 2020

Published: 08 January 2021

Citation:

Mathiesen DS, Lund A, Vilsbøll T, Knop FK and Bagger JI (2021)

Amylin and Calcitonin: Potential

Therapeutic Strategies to Reduce

Body Weight and Liver Fat.

Front. Endocrinol. 11:617400. doi: 10.3389/fendo.2020.617400

\section{Amylin and Calcitonin: Potential Therapeutic Strategies to Reduce Body Weight and Liver Fat}

\author{
David S. Mathiesen ${ }^{1}$, Asger Lund ${ }^{1}$, Tina VilsbølI ${ }^{1,2,3}$, Filip K. Knop ${ }^{1,2,3,4}$ \\ and Jonatan I. Bagger ${ }^{1,4^{*}}$ \\ ${ }^{1}$ Center for Clinical Metabolic Research, Gentofte Hospital, Hellerup, Denmark, 2 Steno Diabetes Center Copenhagen, \\ Gentofte, Denmark, ${ }^{3}$ Department of Clinical Medicine, Faculty of Health and Medical Sciences, University of Copenhagen, \\ Copenhagen, Denmark, ${ }^{4}$ Novo Nordisk Foundation Center for Basic Metabolic Research, Faculty of Health and Medical \\ Sciences, University of Copenhagen, Copenhagen, Denmark
}

The hormones amylin and calcitonin interact with receptors within the same family to exert their effects on the human organism. Calcitonin, derived from thyroid C cells, is known for its inhibitory effect on osteoclasts. Calcitonin of mammalian origin promotes insulin sensitivity, while the more potent calcitonin extracted from salmon additionally inhibits gastric emptying, promotes gallbladder relaxation, increases energy expenditure and induces satiety as well as weight loss. Amylin, derived from pancreatic beta cells, regulates plasma glucose by delaying gastric emptying after meal ingestion, and modulates glucagon secretion and central satiety signals in the brain. Thus, both hormones seem to have metabolic effects of relevance in the context of non-alcoholic fatty liver disease (NAFLD) and other metabolic diseases. In rats, studies with dual amylin and calcitonin receptor agonists have demonstrated robust body weight loss, improved glucose tolerance and a decreased deposition of fat in liver tissue beyond what is observed after a body weight loss. The translational aspects of these preclinical data currently remain unknown. Here, we describe the physiology, pathophysiology, and pharmacological effects of amylin and calcitonin and review preclinical and clinical findings alluding to the future potential of amylin and calcitonin-based drugs for the treatment of obesity and NAFLD.

Keywords: amylin, calcitonin, dual amylin-calcitonin receptor agonist, DACRA, NAFLD, non-alcoholic fatty liver disease, obesity, pramlintide

\section{INTRODUCTION}

Hepatic steatosis is widely regarded the hepatic manifestation of the metabolic syndrome (1). In parallel with the increasing prevalence of obesity and its related diseases, non-alcoholic fatty liver disease (NAFLD) is currently the most widespread liver disease in the world (2-4). Body weight loss is currently the most effective strategy to improve both measures of steatosis and NAFLD outcomes (5) and several anti-obesity medications in clinical development have demonstrated improvements with regards to liver fat content $(6,7)$. Recent preclinical studies have demonstrated body weight loss, reduced hepatic steatosis and metabolic improvements in rats following administration of novel dual amylin and calcitonin receptor agonists (DACRAs) (8-13). 
NAFLD is defined by increased liver fat content $(>5 \%)$ without significant alcohol consumption or steatosis caused by any other mechanism (e.g., medications, hepatitis, autoimmunity or inheritable diseases) $(14,15)$. NAFLD covers a spectrum of stages, ranging from simple accumulation of liver fat to nonalcoholic steatohepatitis (NASH) with inflammation and ultimately to hepatic fibrosis and cirrhosis (1). Recently, the term "metabolic-associated fatty liver disease (MASH)" has been proposed as a unifying definition of hepatic steatosis in individuals with overweight/obesity, metabolic dysregulation and/or manifest type 2 diabetes (16). This definition recognizes the importance of obesity and insulin resistance, rather than the absence of excessive alcohol consumption, as a causal factor for the development of hepatic steatosis. Resonating with this, the prevalence of NAFLD increases dramatically with the number of metabolic syndrome criteria present in a population (17). Furthermore, the wellestablished association between NAFLD and type 2 diabetes highlights a potential casual relationship between impaired glucose metabolism with insulin resistance and hepatic steatosis (18). Even in prediabetes, increased liver fat content is a central characteristic (19). Hepatic lipid accumulation may facilitate resistance to both insulin (20) and glucagon (21), which are important pathophysiological characteristics of type 2 diabetes $(22,23)$. Insulin resistance is regarded a driver of hepatic steatosis through increased hepatic lipogenesis and exaggerated tissue lipolysis, ultimately increasing accumulation of fatty acids in the liver (24).

Currently, bariatric surgery is the most effective weight loss therapy, but it is costly, associates with a non-negligible risk of complications and not all patients are eligible for surgery (25). Therefore, pharmacotherapies to reduce body weight are being vigorously pursued, and amylin as well as DACRAs are emerging as potential novel anti-obesity drug candidates, especially in combination with other body weight-lowering gastrointestinal peptides.

This review summarises amylin and calcitonin physiology and pathophysiology in obesity and NAFLD and provides insight into the potential therapeutic role of pharmacological doses of amylin and calcitonin of relevance to metabolic diseases including obesity and NAFLD.

\section{AMYLIN}

Amylin is a 37-amino acid peptide hormone (Table 1) mainly produced in the pancreatic beta cells and co-secreted with insulin in response to ingested nutrients (Figure 1) $(28,29)$. The hormone has a well-established role as a satiety signal; an effect that is mediated via direct action on amylin receptors in specific areas of the brain, i.e., area postrema and the nucleus of the solitary tract $(30,31)$. Amylin is also an efficacious inhibitor of gastric emptying, which further facilitates satiation (32-34), and may suppress glucagon secretion via central mechanisms $(35,36)$. There are several isotypes of the amylin receptor (37) which all are G proteincoupled receptors consisting of two units; a core unit constituted by the calcitonin receptor (7-transmembrane receptor) and one of three receptor activity-modifying proteins (RAMP1-3) (37). Stimulating the amylin receptor complex increases the

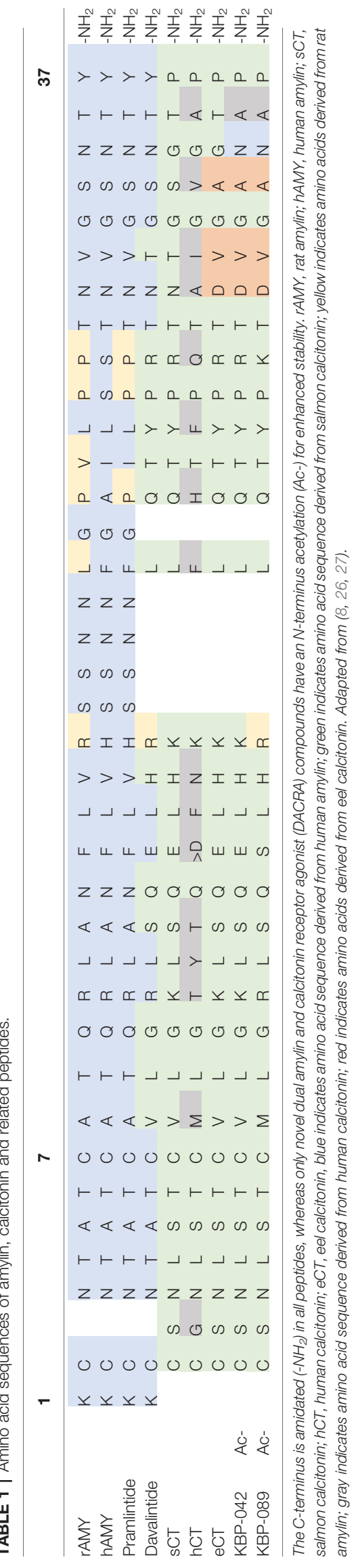




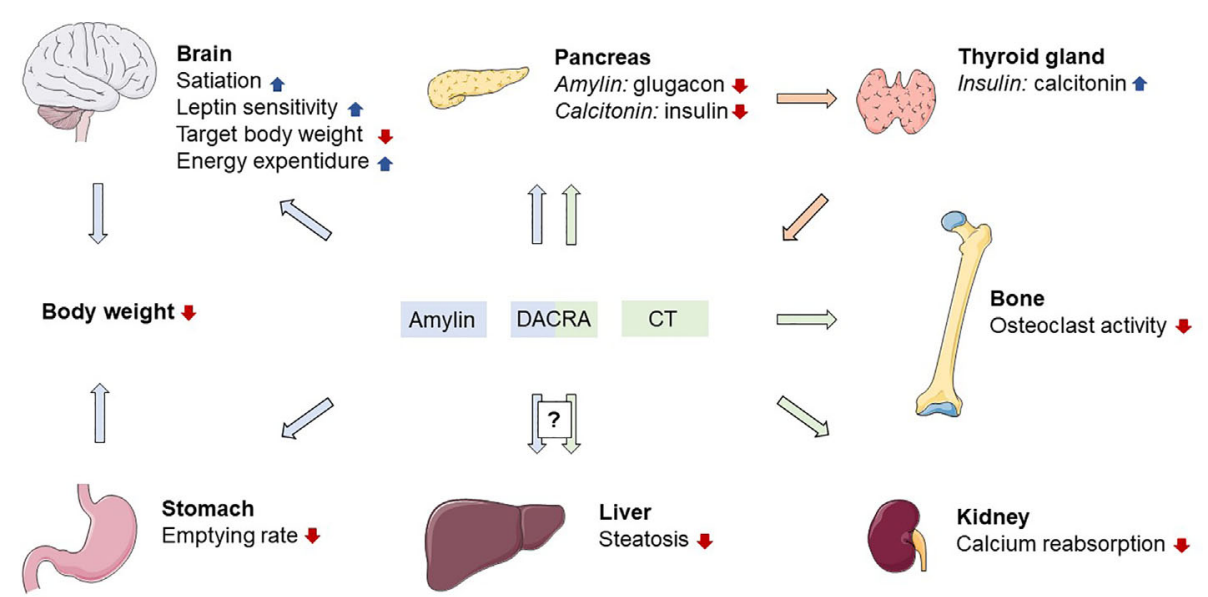

FIGURE 1 | Proposed physiological actions of amylin and calcitonin receptor activation. DACRA, dual amylin and calcitonin receptor agonist; CT, calcitonin; blue arrows indicates effects related to amylin; green arrows indicates effects related to calcitonin; orange arrows indicates effects related to insulin. Figure elements from smart.servier.com under CC BY 3.0.

production of intracellular cyclic adenosine monophosphate (38, 39). The tissue distribution of the amylin receptor complex is difficult to describe for a number of reasons: 1) the calcitonin receptor (the core unit) has two subtypes which interact with RAMPs, 2) RAMPs are associated with other receptors than the amylin receptor complex, and 3) there is a lack of selective pharmacological tools and antibodies to target specific amylin (RAMP/calcitonin) receptor complexes (26). Current data indicate that several brain regions including the area postrema and hypothalamus are important sites for amylin action $(40,41)$. In a knock-out mouse model, lack of the calcitonin receptor specifically in proopiomelanocortin-expressing neurons in the hypothalamus lead to increased adiposity, glucose intolerance and decreased energy expenditure (41). Furthermore, amylin receptors are not selectively activated by amylin alone and interact indiscriminately with other hormones of similar structure (i.e., calcitonin, calcitonin gene-related peptide, and adrenomedullin) (42). Calcitonin, for instance, has been shown to activate several subtypes of the amylin receptor (42). In a similar manner, it has been shown that amylin has affinity for both calcitonin and amylin receptors (43). Several amylin receptor antagonists have been identified, but as alluded to above, these compounds also have selectivity issues, and do not distinguish between amylin receptor subtypes (26). Therefore, the importance of the individual receptor in mediating the endogenous actions of amylin is difficult to establish.

\section{THE ROLE OF AMYLIN IN OBESITY}

Several studies point to a role of amylin in the hormonal regulation of food intake and body weight. Amylin has several characteristics of a satiating hormone: 1) it is released after food ingestion $(28,29), 2)$ it has a short half-life ( 13 min) with rapid onset of action $(44,45)$, and 3$)$ it dose-dependently decreases food intake when administered to rats mainly in supraphysiological doses $(40,45,46)$. This effect also translates into human trials with amylin receptor agonism (see further details below). The role of endogenous amylin as a satiating agent is supported by the observation that injection of the amylin receptor antagonist AC187 intravenously or directly into the area postrema acutely increases food intake in rats $(47,48)$. In addition to its effect on satiety, preclinical studies suggest that endogenous amylin also has the characteristics of an adiposity signal (i.e., a body weightregulatory hormonal factor circulating in proportion with body fat mass), much like insulin and leptin, namely the ability to increase energy expenditure and lower body weight via central mechanisms $(49,50)$. In rats, chronic intravenous administration of amylin leads to body weight loss and diminished fat deposition, whereas centrally administered amylin, in addition to lowering body weight, also seems to reduce the target body weight set by the brain (49-52). Supporting its role as an endogenous adiposity signal, acute and chronic amylin antagonism with AC187 has the opposing effect and increases food intake and body weight of rats (50). As an adiposity signal, amylin enhances the satiating effect of cholecystokinin (CCK). This is evidenced by the synergistic acute effect of co-administered CCK and amylin on food intake when infused intraperitoneally in mice (53) and further supported by the diminished action of CCK in mice models of amylin deficiency (54) and in rats after infusion of amylin receptor antagonists (55, 56). Chronic intraperitoneal infusion of CCK decreases food intake in rats, but has little effect on body weight due to a compensatory increase in meal frequency (57). Contrary to this, chronic subcutaneous infusion of amylin reduces both meal size and frequency with concomitant body weight loss in rats (46). Interestingly, amylin also interacts with leptin in the control of energy metabolism in a number of preclinical studies, supporting its combined role as a satiety and adiposity signal (58-61). In rats with obesity or functional leptin resistance, the effect of amylin agonism on eating behaviour is still observed for $24 \mathrm{~h}$ after injection of an amylin agonist (58). Furthermore, intraventricular administration of leptin seems to enhance the inhibitory effect of amylin on 
short-term eating, suggesting synergism in the actions of these hormones (59). Additionally, amylin re-sensitizes obese rats to leptin when co-administered with a leptin agonist for 14 days (60). As opposed to leptin, amylin show a preserved anorectic response when investigating obese and hyperamylinaemic rats (61). In fact, several rodent studies suggest a well-preserved anorectic response to acute amylin administration in otherwise obese and leptin-resistant states $(26,60,61)$, thus making amylin a promising candidate for pharmaceutical weight loss therapy. Furthermore, an additive effect on weight loss is also observed in obese individuals when amylin and leptin agonists are chronically co-administered, adding further evidence to the interaction between leptin and amylin (60). The chemical properties of human amylin predisposes the hormone to aggregate and form amyloid fibrils, which are often found in pancreatic islets of individuals with type 2 diabetes and possibly contribute to beta cell destruction (62). For this reason, infusions of human amylin are difficult to perform, often requiring highly supraphysiological dosages to elicit little or no effect $(63,64)$. However, several stable amylin analogues with the ability to induce body weight loss have been developed (further details below).

Taken together, amylin has acute effects as a satiety signal combined with homeostatic effects of an adiposity signal on body weight, suggesting an important role of amylin in the regulation of body mass. In clinical trials, circulating amylin levels seem to tightly correlate with fat mass. Studies indicate that basal and glucose or meal-stimulated levels of amylin are elevated in individuals with obesity (65-74). This may relate to the role of amylin as a regulator of body mass but could also be a manifestation of the increased beta cell secretory activity often found in obesity. These studies are generally limited by their sample size and contrasting reports have been published (75). Preclinical studies support the notion of elevated amylin levels in rats with obesity $(76,77)$. This might be a result of decreased amylin sensitivity following prolonged hyperamylinaemia, but there is currently no evidence of this in humans. More studies designed to specifically evaluate amylin secretion and sensitivity in individuals with obesity compared to individuals with normal weight are needed.

\section{CALCITONIN}

Calcitonin is a 32-amino acid peptide hormone (Table 1) derived from the 116-amino acid precursor pro-calcitonin and secreted from the $\mathrm{C}$ cells of the thyroid gland. As alluded to above, calcitonin mediates its effects via the 7-transmembrane calcitonin receptor and a subsequent increase in intracellular cAMP (38). Due to the interaction with RAMPs, the tissue distribution of the monomeric calcitonin receptor is challenging to elaborate, but well-known target organs of calcitonin include bones and kidneys $(78,79)$. In humans the secretion of calcitonin is stimulated by ingestion of calcium (80). Calcitonin has a strong hypocalcaemic effect via inhibition of osteoclasts (Figure 1) (79) and promotion of renal excretion of calcium, presumably by inhibiting tubular reabsorption of calcium (79). Since the discovery of calcitonin in 1962 (81), great effort has been put into the description of its inhibitory effect on osteoclasts and the increased calcium excretion in humans whereas any other physiological effects have not been described. Human calcitonin is often considered a rudimentary hormone, mainly due to the fact that hypersecretion or deficiency of calcitonin (as seen in patients with thyroid medullary cancer) is not associated with bone abnormalities (82). Furthermore, the more potent form of calcitonin originating from salmon has been the preferred choice of treatment for chronic conditions with hypercalcaemia until better antiresorptive drugs emerged (e.g., bisphosphonates, denosumab and raloxifen) (83).

\section{CALCITONIN IN METABOLIC DISEASE}

It is difficult to evaluate the role of endogenous calcitonin in metabolic diseases for a number of reasons: 1) only few studies have applied human calcitonin in humans, 2) there are currently no antagonists available which selectively target the monomeric calcitonin receptor (26), and 3) studies applying the more potent salmon calcitonin reveal effects attributable to amylin receptor activity as well (84). As reviewed in the following sections, the actions of salmon and human calcitonin are not directly comparable. A few studies have used mammalian calcitonin to investigate effects beyond those related to calcium and bone metabolism. Interestingly, both human and porcine calcitonin infusions inhibit the insulin response to acute glucose administration in humans (85-87). But whether this effect has physiological relevance remains to be determined. In a study with 26 subjects, who were mainly overweight but with normal glucose tolerance, there was an increase in serum calcitonin levels after a 75-g oral glucose tolerance test which correlated with insulin levels, suggesting a possible relationship between insulin and calcitonin (88). This is in concert with the observation that insulin directly stimulates calcitonin release in the perfused pig thyroid gland (89). Additionally, higher endogenous calcitonin levels in individuals with obesity has been reported (90). Finally, procalcitonin is expressed in adipose tissue and its expression associates with obesity, insulin resistance and metabolic syndrome (91). Taken together, research thus far gives some indication that a correlation between calcitonin and insulin might exist in man, but studies designed specifically to affirm this are warranted.

\section{AMYLIN AND CALCITONIN-BASED PHARMACOTHERAPIES}

\section{Pramlintide}

Pramlintide is a Food and Drug Administration (FDA)approved amylin analogue, developed for individuals with type 1 diabetes or insulin-treated type 2 diabetes as an adjunct therapy to mealtime insulin (92). Pramlintide has pharmacological properties comparable to human amylin, but with enhanced stability, thus making it suitable for subcutaneous administration in humans (44). It is a relatively short-lived peptide with a halflife of $\sim 20-45 \mathrm{~min}$ in humans, thus requiring administration with every meal to diminish postprandial plasma glucose 
excursions $(44,93)$. Inspired by rat amylin, which is less prone to dimerize, the enhanced stability of pramlintide compared to human amylin was achieved by introducing three amino acid substitutions (pro25,28,29) into the sequence of human amylin (26) (Table 1). In addition to reducing postprandial plasma glucose excursions, pramlintide has demonstrated body weightlowering capabilities in several clinical trials (94-112). In a 6week randomised, blinded, placebo-controlled multicentre trial, 60 obese individuals (average body mass index (BMI) $=35.3 \mathrm{~kg} /$ $\mathrm{m}^{2}$ ) were titrated to $180 \mu \mathrm{g}$ pramlintide injected subcutaneously before each meal to test the translatability of the body weight loss observed in trials with pramlintide in individuals with diabetes (94). After 6 weeks, the mean change in body weight from baseline was $-2.04 \mathrm{~kg}$, corresponding to a weight loss of roughly $2 \%$. This was highly significant compared to the placebo group. In a 4-month trial of similar design, the majority (88\%) of 108 obese individuals (average $\mathrm{BMI}=37.9 \mathrm{~kg} / \mathrm{m}^{2}$ ) were titrated to $240 \mu \mathrm{g}$ meal time pramlintide injected subcutaneously three times daily (95). The resulting average body weight loss of $3.7 \%$ was highly significant compared to the placebo group. To evaluate the sustainability of these results, a 12-month randomised, double-blinded, placebocontrolled multicentre trial with 146 obese subjects (average BMI $37 \mathrm{~kg} / \mathrm{m}^{2}$ ) evaluated the effect of pramlintide combined with lifestyle intervention on long-term body weight loss (96). An initial 4month dose escalation period evaluated different doses (120, 240, and $360 \mu \mathrm{g}$ ) and administration frequencies (two or three times daily) for pramlintide and was followed by an 8-month extension of the pre-assigned pramlintide treatment regime. At 4 months, body weight reduction was comparable to previous pramlintide trials, ranging from 3.8 to $6.1 \mathrm{~kg}$ depending on pramlintide dose. Interestingly, after 12 months, the body weight loss was sustained across all pramlintide treatment regimens except for those treated with $120 \mu \mathrm{g}$ twice daily. This is encouraging, as gradual body weight regain is a common observation following lifestyle-induced weight loss $(97,113,114)$. In obese individuals with insulin-treated type 2 diabetes, pramlintide dose-dependently reduces body weight (98104). The body weight-lowering effect of pramlintide is also seen in individuals with type 1 diabetes (105-112).

As outlined above, pramlintide treatment is associated with $2 \%-$ $6 \%$ reductions in body weight across several patient categories, including individuals with obesity and type 2 diabetes, who are prone to develop hepatic steatosis. This makes amylin-based pharmacology a promising candidate for the treatment of obesity and NAFLD. However, long-term pramlintide treatment is limited by low bioavailability and the short half-life of the drug, which makes it less suitable for chronic therapy due to the high administration frequency (two to three times daily) and therefore high compliance-related demands. Additionally, pramlintide monotherapy only has a modest effect on body weight loss compared to for example glucagon-like peptide 1 (GLP-1) receptor agonists (115) or the more dramatic changes observed after bariatric surgery (116). Pharmacotherapies targeting several mechanisms are currently being extensively explored as potential weight loss strategies (117). In preclinical and clinical settings, amylin has been combined with several other compounds with weight regulatory abilities to elicit beneficial effects on body weight.
These include agents based on peptide YY (PYY), CCK, melanocortins, leptin, and GLP-1 as well as small molecule anorectics (phentermine/sibutramine) (54, 118-123). Only the GLP-1/amylin combination is currently being developed for obesity treatment in clinical trials (124). Later in this section, we review the effect of targeting multiple receptors in the calcitonin receptor family via novel unimolecular dual agonists, but first we briefly consider results from studies with other amylinbased agents.

\section{Davalintide}

Davalintide is a 32-amino acid peptide amylin receptor agonist (Table 1) with enhanced potency, efficacy and duration of action compared to amylin in rats (125). Davalintide was developed in response to the low bioavailability and short half-life which rendered pramlintide therapy for obesity inefficient. The peptide is a chimera of amylin and salmon calcitonin and shares $49 \%$ of the amino acid sequence of rat amylin and pramlintide $(26,125)$. The half-life of davalintide is $26 \mathrm{~min}$, and thus, comparable to rat amylin (126). However, davalintide reduces food consumption in rats for up to $23 \mathrm{~h}$, compared to only $6 \mathrm{~h}$ with rat amylin (125). Further, davalintide dose-dependently reduces body weight and fat mass in rats with approximately 2 -fold greater efficacy than rat amylin (125). The prolonged duration is likely explained by slow receptor disassociation of the salmon calcitonin portion of davalintide (38, 127). Indeed, receptor binding analysis revealed very limited receptor disassociation of davalintide in the rat nucleus accumbens (126). As of now, these preclinical studies with davalintide represent the only available literature on davalintide and further development of davalintide in humans trials have been discontinued due to lack of superiority to pramlintide on weight loss (128). Nevertheless, these few trials with davalintide illustrate how the calcitonin receptor system may constitute a target for the treatment of obesity and associated metabolic conditions such as NAFLD.

\section{Long-Acting Amylin Agonists}

Amylin has been modified by various methods (e.g., by adding a polyethylene glycol (PEG), glycosylation, or albumin binding motif to the molecule) to extend its half-life and reduce the frequency of administration, thus making it more suitable for chronic use in body weight loss therapy (129-135). In mice, subcutaneous administration of PEGylated amylin acutely reduces glycaemia with prolonged action compared to unmodified amylin (129). In rat models of type 1 diabetes, a PEGylated amylin analogue prevented meal-induced hyperglycaemia and promoted sustained normoglycaemia up to $8 \mathrm{~h}$ after injection of the amylin analogue (132). Importantly, acute and chronic studies show that long-acting amylin analogues decrease body weight and energy intake in rats $(136,137)$. Given the convenience of a once-daily injection compared to several daily injections, long-acting amylin agonists are attractive to develop and are currently being pursued as novel anti-obesity and anti-diabetes drug candidates by multiple pharmaceutical companies. Novo Nordisk is currently testing a long-acting amylin analogue, AM833, in overweight and obese individuals in phase I and II clinical trials $(138,139)$. In a recently 
published phase II trial, the effect of life style interventions along with increasing doses $(0.3,0.6,1.2,2.4$ and $4.5 \mathrm{mg})$ of AM833 once weekly on body weight was investigated 706 individuals with obesity/overweight (140). At 26 weeks, body weight had decreased progressively and dose-dependently without plateau, with reductions ranging from $6 \%-10.8 \%$. Compared to placebo and $3 \mathrm{mg}$ liraglutide once daily, the observed weight loss amongst participants receiving AM833 was significantly greater for all doses of AM833 versus placebo and for $4.5 \mathrm{mg}$ once weekly versus liraglutide. AM833 has also been evaluated for use in combination with the GLP-1 analogue semaglutide in a phase I clinical trial (124, 141). A total of 80 participants with obesity or overweight were treated with ascending doses of AM833 in combination with 2.4 mg semaglutide once-weekly (141). After 20 weeks, the participants receiving the highest dose of AM833 with semaglutide lost an average of $17.1 \%$ body weight from baseline (141). Also, Zealand Pharma is developing long-acting amylin analogues for treatment of obesity and diabetes $(142,143)$. Preclinical data from diabetic and obese rats models have been released for the compounds ZP4982 and ZP5461; both molecules are potent activators of calcitonin and amylin receptors and effectively lower blood glucose and body weight $(142,143)$. Compared to twice-daily preclinical dosing with the GLP-1 analogue liraglutide, onceweekly dosing of ZP4982 at almost equimolar doses was superior in terms of body weight loss in an obese rat model (143). A phase I clinical trial was conducted with a long-acting amylin analogue developed by Zealand Pharma in cooperation with Boehringer Ingelheim in 2018, but the collaboration on this analogue was terminated in $2020(144,145)$.

\section{Salmon Calcitonin}

Calcitonin extracted from salmon displays prolonged receptor activation and binding in humans compared with human calcitonin (38). It is also superior to mammalian calcitonin with regards to its hypocalcaemic effects in rats and humans (146). Interestingly, salmon calcitonin has effects beyond those related to bone metabolism. In human studies, salmon calcitonin inhibits gastric emptying and gastrin release following a meal while evoking a dose-dependent relaxation of the gallbladder both in the postprandial and fasting state $(147,148)$. In mice and monkeys, salmon calcitonin acts anorectically and causes weight loss after a single administration $(149,150)$. In chronic studies, oral preparations of salmon calcitonin also reduce food intake and body weight in rat models of obesity and diabetes (151, 152). Furthermore, salmon calcitonin acutely stimulates energy expenditure during food restriction in rats (153). Human and salmon calcitonin only have a $50 \%$ amino acid sequence homology (38) (Table 1), and rodent studies applying amylin receptor antagonists suggest that the anorectic effect of salmon calcitonin results at least partially from amylin receptor activation (84). In vitro, salmon calcitonin displays superior binding affinity at amylin receptors with no discrimination between amylin and calcitonin receptors (154). Compared to human calcitonin, salmon calcitonin also displays prolonged activation of human calcitonin receptors when tested in mammalian cell lines expressing the calcitonin receptor (38). This suggests that salmon calcitonin is a dual agonist with potency at amylin and calcitonin receptors, highlighting the possibility of targeting these receptors using a single molecule with dual-receptor agonistic properties.

\section{Dual Amylin and Calcitonin Receptor Agonists}

Inspired by the pharmacology of salmon calcitonin, DACRAs for the treatment of obesity and diabetes have been developed (8-13). DACRAs display equal affinity and enhanced potency at amylin and calcitonin receptors compared to salmon calcitonin (8). In Zucker diabetic fatty rats, 4-week treatment with the DACRA KBP-042 from Nordic Bioscience was compared with salmon calcitonin and vehicle in a pair-fed design; showing significant weight loss and improved glucose tolerance compared to both vehicle and salmon calcitonin (8). In other studies, subcutaneous injections with KBP-042 lead to substantial body weight loss with alleviation of leptin and insulin resistance in rats on high-fat diet compared to rats on normal diet $(11,12)$. Interestingly, after a 7 week treatment period, a reduction in liver fat deposition was observed in the KBP-042-treated rats, but not in a pair-fed control group of rats (12). The ability to reduce hepatic lipid accumulation has also been demonstrated with another DACRA, KBP-089 (10). In rats subjected to a high-fat diet without therapy for 10 weeks and subsequently to subcutaneous peptide therapy for 8 weeks, KBP-089 completely abolished the hepatic steatosis achieved by the initial high-fat feeding (10). Importantly, this effect was not observed in a pair-fed group of rats, suggesting that DACRA therapy has beneficial effects on hepatic steatosis beyond those related to reduced food intake and weight loss. These peptides show promise in terms of their effects on body weight and several physiological parameters related to energy homeostasis and glucose metabolism in rodent models of obesity and diabetes. From the available literature, it is not clear to which degree the amylin and calcitonin receptor mediates the beneficial results obtained in preclinical DACRA studies. In a rodent study comparing the activity of a DACRA molecule to native amylin, calcitonin and the combination amylin/calcitonin, calcitonin receptor activation did not appear to be important for the weight lowering and satiating abilities of the DACRA molecule, which were primarily mediated by the amylin receptor (155). On the other hand, calcitonin and amylin had additive effects on fasting glycaemia, suggesting that calcitonin receptor activity may facilitate some of the metabolic improvements of DACRA molecules after all (155).

A 12-week phase II placebo-controlled clinical trial with 255 patients with type 2 diabetes receiving KBP-042 has been completed (156), but further development of KBP-042 has been terminated by Eli Lilly and Nordic Bioscience to focus on the development of KBP-089, which is reportedly superior to KBP-042 (157, 158). KBP-089 is currently being tested in a phase I clinical trial in patients with type 2 diabetes (159). As of now, no results from clinical trials with DACRA molecules have been published. Thus, it remains to be established whether the promising preclinical results obtained with DACRA peptides will translate into possible treatment strategies for metabolic diseases such as obesity and NAFLD. 


\section{CONCLUSIONS}

A substantial amount of literature describes beneficial metabolic effects of compounds activating amylin and calcitonin receptors separately or in combination. These effects include body weight loss and reduced hepatic lipid accumulation, which are important cornerstones in the treatment of obesity and NAFLD. Pharmaceutical companies are pursuing strategies based on amylin and calcitonin as viable alternatives to bariatric surgery, the currently most effective treatment option for obesity.

Preclinical and clinical data support amylin as an anti-obesity hormone, whereas the role of calcitonin in obesity remains more uncertain. Nevertheless, salmon calcitonin, like new compounds such as long-acting amylin analogues and DACRAs, demonstrates a potential for combined amylin and calcitonin receptor agonism as a future treatment strategy for obesity and related conditions such as NAFLD. Disentangling the effects of these dual agonists through specific amylin and calcitonin pathways may prove to be difficult

\section{REFERENCES}

1. Buzzetti E, Pinzani M, Tsochatzis EA. The multiple-hit pathogenesis of nonalcoholic fatty liver disease (NAFLD). Metabolism (2016) 65:1038-48. doi: 10.1016/j.metabol.2015.12.012

2. Younossi ZM, Koenig AB, Abdelatif D, Fazel Y, Henry L, Wymer M. Global epidemiology of nonalcoholic fatty liver disease-Meta-analytic assessment of prevalence, incidence, and outcomes. Hepatology (2016) 64:73-84. doi: 10.1002/hep.28431

3. Leoni S, Tovoli F, Napoli L, Serio I, Ferri S, Bolondi L. Current guidelines for the management of non-alcoholic fatty liver disease: A systematic review with comparative analysis. World J Gastroenterol (2018) 24:3361-73. doi: 10.3748/wjg.v24.i30.3361

4. Marjot T, Moolla A, Cobbold JF, Hodson L, Tomlinson JW. Nonalcoholic Fatty Liver Disease in Adults: Current Concepts in Etiology, Outcomes, and Management. Endocr Rev (2020) 41:66-117. doi: 10.1210/endrev/bnz009

5. Musso G, Cassader M, Rosina F, Gambino R. Impact of current treatments on liver disease, glucose metabolism and cardiovascular risk in nonalcoholic fatty liver disease (NAFLD): a systematic review and metaanalysis of randomised trials. Diabetologia (2012) 55:885-904. doi: 10.1007/s00125-011-2446-4

6. Armstrong MJ, Hull D, Guo K, Barton D, Hazlehurst JM, Gathercole LL, et al. Glucagon-like peptide 1 decreases lipotoxicity in non-alcoholic steatohepatitis. J Hepatol (2016) 64:399-408. doi: 10.1016/j.jhep.2015.08.038

7. Assy N, Hussein O, Abassi Z. Weight loss induced by orlistat reverses fatty infiltration and improves hepatic fibrosis in obese patients with nonalcoholic steatohepatitis. Gut (2007) 56:443-4. doi: 10.1136/gut.2006.106021

8. Andreassen KV, Feigh M, Hjuler ST, Gydesen S, Henriksen JE, Beck-Nielsen $\mathrm{H}$, et al. A novel oral dual amylin and calcitonin receptor agonist (KBP-042) exerts antiobesity and antidiabetic effects in rats. Am J Physiol Endocrinol Metab (2014) 307:E24-33. doi: 10.1152/ajpendo.00121.2014

9. Gydesen S, Andreassen KV, Hjuler ST, Christensen JM, Karsdal MA, Henriksen K. KBP-088, a novel DACRA with prolonged receptor activation, is superior to davalintide in terms of efficacy on body weight. Am J Physiol Endocrinol Metab (2016) 310:E821-7. doi: 10.1152/ajpendo.00514.2015

10. Gydesen S, Hjuler ST, Freving Z, Andreassen KV, Sonne N, Hellgren LI, et al. A novel dual amylin and calcitonin receptor agonist, KBP-089, induces weight loss through a reduction in fat, but not lean mass, while improving food preference. Br J Pharmacol (2017) 174:591-602. doi: 10.1111/bph.13723

11. Hjuler ST, Andreassen KV, Gydesen S, Karsdal MA, Henriksen K. KBP-042 improves bodyweight and glucose homeostasis with indices of increased insulin sensitivity irrespective of route of administration. Eur J Pharmacol (2015) 762:229-38. doi: 10.1016/j.ejphar.2015.05.051 without specific receptor antagonists. Nevertheless, it is relevant to evaluate from a clinical perspective in order to optimize the effects of pharmacotherapy targeting amylin and calcitonin receptors. Data from the clinical programs investigating the new amylin and DACRA compounds will be very interesting to follow since longacting agonists with greater selectivity at amylin or calcitonin receptors may help elucidate this. However, dedicated studies are needed to test the translatability of the preclinical data of amylin and calcitonin dual agonism and to delineate the separate and combined physiological effects of amylin and/or calcitonin receptor activity in humans.

\section{AUTHOR CONTRIBUTIONS}

DM drafted the manuscript. AL, TV, FK, and JB reviewed and edited the manuscript. All authors contributed to the article and approved the submitted version.

12. Hjuler ST, Gydesen S, Andreassen KV, Pedersen SLK, Hellgren LI, Karsdal $\mathrm{MA}$, et al. The dual amylin- and calcitonin-receptor agonist KBP-042 increases insulin sensitivity and induces weight loss in rats with obesity. Obesity (2016) 24:1712-22. doi: 10.1002/oby.21563

13. Sonne N, Larsen AT, Andreassen KV, Karsdal MA, Henriksen K. The Dual Amylin and Calcitonin Receptor Agonist, KBP-066, Induces an Equally Potent Weight Loss Across a Broad Dose Range While Higher Doses May Further Improve Insulin Action. J Pharmacol Exp Ther (2020) 373:92-102. doi: 10.1124/jpet.119.263723

14. European Association for the Study of the Liver (EASL), European Association for the Study of Diabetes (EASD) and European Association for the Study of Obesity (EASO). EASL-EASD-EASO Clinical Practice Guidelines for the management of non-alcoholic fatty liver disease. J Hepatol (2016) 64:1388-402. doi: 10.1016/j.jhep.2015.11.004

15. Chalasani N, Younossi Z, Lavine JE, Charlton M, Cusi K, Rinella M, et al The diagnosis and management of nonalcoholic fatty liver disease: Practice guidance from the American Association for the Study of Liver Diseases. Hepatology (2018) 67:328-57. doi: 10.1002/hep.29367

16. Eslam M, Newsome PN, Sarin SK, Anstee QM, Targher G, Romero-Gomez M, et al. A new definition for metabolic dysfunction-associated fatty liver disease: An international expert consensus statement. J Hepatol (2020) 73:202-9. doi: 10.1016/j.jhep.2020.03.039

17. Jinjuvadia R, Antaki F, Lohia P, Liangpunsakul S. The Association between Nonalcoholic Fatty Liver Disease and Metabolic Abnormalities in United States Population. I Clin Gastroenterol (2017) 51:160-6. doi: 10.1097/ MCG.0000000000000666

18. Dai W, Ye L, Liu A, Wen SW, Deng J, Wu X, et al. Prevalence of nonalcoholic fatty liver disease in patients with type 2 diabetes mellitus. Med (Baltimore) (2017) 96:e8179. doi: 10.1097/MD.0000000000008179

19. Kotronen A, Peltonen M, Hakkarainen A, Sevastianova K, Bergholm R, Johansson LM, et al. Prediction of non-alcoholic fatty liver disease and liver fat using metabolic and genetic factors. Gastroenterology (2009) 137:865-72. doi: 10.1053/j.gastro.2009.06.005

20. Petersen KF, Dufour S, Befroy D, Lehrke M, Hendler RE, Shulman GI Reversal of Nonalcoholic Hepatic Steatosis, Hepatic Insulin Resistance, and Hyperglycemia by Moderate Weight Reduction in Patients With Type 2 Diabetes. Diabetes (2005) 54:603-8. doi: 10.2337/diabetes.54.3.603

21. Suppli MP, Bagger JI, Lund A, Demant M, van Hall G, Strandberg C, et al. Glucagon Resistance at the Level of Amino Acid Turnover in Obese Subjects With Hepatic Steatosis. Diabetes (2020) 69:1090-9. doi: 10.2337/db190715

22. Unger RH, Orci L. Glucagon and the a Cell. New Engl J Med (1981) 304:1518-24. doi: 10.1056/NEJM198106183042504 
23. Martin BC, Warram JH, Krolewski AS, Bergman RN, Soeldner JS, Kahn CR. Role of glucose and insulin resistance in development of type 2 diabetes mellitus: results of a 25-year follow-up study. Lancet (1992) 340:925-9. doi: 10.1016/0140-6736(92)92814-v

24. Bugianesi E, Moscatiello S, Ciaravella MF, Marchesini G. Insulin resistance in nonalcoholic fatty liver disease. Curr Pharm Des (2010) 16:1941-51. doi: $10.2174 / 138161210791208875$

25. Neff K, Olbers T, le Roux C. Bariatric surgery: the challenges with candidate selection, individualizing treatment and clinical outcomes. BMC Med (2013) 11:8. doi: 10.1186/1741-7015-11-8

26. Hay DL, Chen S, Lutz TA, Parkes DG, Roth JD. Amylin: Pharmacology, Physiology, and Clinical Potential. Pharmacol Rev (2015) 67:564-600. doi: 10.1124/pr.115.010629

27. Gydesen S, Andreassen KV, Hjuler ST, Hellgren LI, Karsdal MA, Henriksen K. Optimization of tolerability and efficacy of the novel dual amylin and calcitonin receptor agonist KBP-089 through dose escalation and combination with a GLP-1 analog. Am J Physiol Endocrinol Metab (2017) 313:E598-607. doi: 10.1152/ajpendo.00419.2016

28. Hartter E, Svoboda T, Ludvik B, Schuller M, Lell B, Kuenburg E, et al. Basal and stimulated plasma levels of pancreatic amylin indicate its co-secretion with insulin in humans. Diabetologia (1991) 34:52-4. doi: 10.1007/BF00404025

29. Butler PC, Chou J, Carter WB, Wang Y-N, Bu B-H, Chang D, et al. Effects of Meal Ingestion on Plasma Amylin Concentration in NIDDM and Nondiabetic Humans. Diabetes (1990) 39:752-6. doi: 10.2337/diab.39.6.752

30. Potes CS, Lutz TA. Brainstem mechanisms of amylin-induced anorexia. Physiol Behav (2010) 100:511-8. doi: 10.1016/j.physbeh.2010.03.001

31. Boyle CN, Lutz TA, Le Foll C. Amylin - Its role in the homeostatic and hedonic control of eating and recent developments of amylin analogs to treat obesity. Mol Metab (2017) 8:203-10. doi: 10.1016/j.molmet.2017.11.009

32. Young AA, Gedulin BR, Rink TJ. Dose-responses for the slowing of gastric emptying in a rodent model by glucagon-like peptide (7-36) NH2, amylin, cholecystokinin, and other possible regulators of nutrient uptake. Metab Clin $\operatorname{Exp}$ (1996) 45:1-3. doi: 10.1016/s0026-0495(96)90192-4

33. Kong M-F, King P, Macdonald IA, Stubbs TA, Perkins AC, Blackshaw PE, et al. Infusion of pramlintide, a human amylin analogue, delays gastric emptying in men with IDDM. Diabetologia (1997) 40:82-8. doi: 10.1007/s001250050646

34. Halawi H, Camilleri M, Acosta A, Vazquez-Roque M, Oduyebo I, Burton D, et al. Relationship of gastric emptying or accommodation with satiation, satiety, and postprandial symptoms in health. Am J Physiol Gastrointest Liver Physiol (2017) 313:G442-7. doi: 10.1152/ajpgi.00190.2017

35. Gedulin BR, Rink TJ, Young AA. Dose-response for glucagonostatic effect of amylin in rats. Metab Clin Exp (1997) 46:67-70. doi: 10.1016/S0026-0495 (97)90170-0

36. Silvestre RA, Rodríguez-Gallardo J, Jodka C, Parkes DG, Pittner RA, Young AA, et al. Selective amylin inhibition of the glucagon response to arginine is extrinsic to the pancreas. Am J Physiol Endocrinol Metab (2001) 280:E443-9. doi: 10.1152/ajpendo.2001.280.3.E443

37. McLatchie LM, Fraser NJ, Main MJ, Wise A, Brown J, Thompson N, et al. RAMPs regulate the transport and ligand specificity of the calcitoninreceptor-like receptor. Nature (1998) 393:333-9. doi: 10.1038/30666

38. Andreassen KV, Hjuler ST, Furness SG, Sexton PM, Christopoulos A, Nosjean O, et al. Prolonged Calcitonin Receptor Signaling by Salmon, but Not Human Calcitonin, Reveals Ligand Bias. PloS One (2014) 9(3):e92042. doi: 10.1371/journal.pone.0092042

39. Christopoulos G, Perry KJ, Morfis M, Tilakaratne N, Gao Y, Fraser NJ, et al. Multiple Amylin Receptors Arise from Receptor Activity-Modifying Protein Interaction with the Calcitonin Receptor Gene Product. Mol Pharmacol (1999) 56:235-42. doi: 10.1124/mol.56.1.235

40. Lutz TA. Amylinergic control of food intake. Physiol Behav (2006) 89:46571. doi: 10.1016/j.physbeh.2006.04.001

41. Coester B, Koester-Hegmann C, Lutz TA, Foll CL. Amylin/Calcitonin Receptor-Mediated Signaling in POMC Neurons Influences Energy Balance and Locomotor Activity in Chow-Fed Male Mice. Diabetes (2020) 69(6):1110-25. doi: 10.2337/db19-0849

42. Hay DL, Christopoulos G, Christopoulos A, Poyner DR, Sexton PM. Pharmacological Discrimination of Calcitonin Receptor: Receptor Activity-Modifying Protein Complexes. Mol Pharmacol (2005) 67:165565. doi: $10.1124 / \mathrm{mol} .104 .008615$
43. Gingell JJ, Burns ER, Hay DL. Activity of Pramlintide, Rat and Human Amylin but not A $31-42$ at Human Amylin Receptors. Endocrinology (2014) 155:21-6. doi: 10.1210/en.2013-1658

44. Young AA, Vine W, Gedulin BR, Pittner R, Janes S, Gaeta LSL, et al. Preclinical pharmacology of pramlintide in the rat: Comparisons with human and rat amylin. Drug Dev Res (1996) 37:231-48. doi: 10.1002/ (SICI)1098-2299(199604)37:4<231::AID-DDR5>3.0.CO;2-M

45. Lutz TA, Geary N, Szabady MM, Del Prete E, Scharrer E. Amylin decreases meal size in rats. Physiol Behav (1995) 58:1197-202. doi: 10.1016/0031-9384 (95)02067-5

46. Arnelo U, Permert J, Adrian TE, Larsson J, Westermark P, Reidelberger RD. Chronic infusion of islet amyloid polypeptide causes anorexia in rats. Am J Physiol Regul Integr Comp Physiol (1996) 271:R1654-9. doi: 10.1152/ ajpregu.1996.271.6.R1654

47. Mollet A, Gilg S, Riediger T, Lutz TA. Infusion of the amylin antagonist AC 187 into the area postrema increases food intake in rats. Physiol Behav (2004) 81:149-55. doi: 10.1016/j.physbeh.2004.01.006

48. Reidelberger RD, Haver AC, Arnelo U, Smith DD, Schaffert CS, Permert J. Amylin receptor blockade stimulates food intake in rats. Am J Physiol Regul Integr Comp Physiol (2004) 287:R568-74. doi: 10.1152/ajpregu.00213.2004

49. WIELINGA PY, LÖWENSTEIN C, MUFF S, MUNZ M, WOODS SC, LUTZ TA. CENTRAL AMYLIN ACTS AS AN ADIPOSITY SIGNAL TO CONTROL BODY WEIGHT AND ENERGY EXPENDITURE. Physiol Behav (2010) 101:45-52. doi: 10.1016/j.physbeh.2010.04.012

50. Rushing PA, Hagan MM, Seeley RJ, Lutz TA, D'Alessio DA, Air EL, et al. Inhibition of central amylin signaling increases food intake and body adiposity in rats. Endocrinology (2001) 142:5035. doi: 10.1210/endo.142.11.8593

51. Roth JD, Hughes H, Kendall E, Baron AD, Anderson CM. Antiobesity effects of the beta-cell hormone amylin in diet-induced obese rats: effects on food intake, body weight, composition, energy expenditure, and gene expression. Endocrinology (2006) 147:5855-64. doi: 10.1210/en.2006-0393

52. Mack C, Wilson J, Athanacio J, Reynolds J, Laugero K, Guss S, et al. Pharmacological actions of the peptide hormone amylin in the long-term regulation of food intake, food preference, and body weight. Am J Physiol Regul Integr Comp Physiol (2007) 293:R1855-63. doi: 10.1152/ ajpregu.00297.2007

53. Bhavsar S, Watkins J, Young A. Synergy between amylin and cholecystokinin for inhibition of food intake in mice. Physiol Behav (1998) 64:557-61. doi: 10.1016/s0031-9384(98)00110-3

54. Mollet A, Meier S, Grabler V, Gilg S, Scharrer E, Lutz TA. Endogenous amylin contributes to the anorectic effects of cholecystokinin and bombesin. Peptides (2003) 24:91-8. doi: 10.1016/s0196-9781(02)00280-2

55. Lutz TA, Del Prete E, Szabady MM, Scharrer E. Attenuation of the anorectic effects of glucagon, cholecystokinin, and bombesin by the amylin receptor antagonist CGRP(8-37). Peptides (1996) 17:119-24. doi: 10.1016/0196-9781 (95)02046-2

56. Lutz TA, Tschudy S, Rushing PA, Scharrer E. Attenuation of the anorectic effects of cholecystokinin and bombesin by the specific amylin antagonist AC 253 Physiol Behav (2000) 70:533-6. doi: 10.1016/s0031-9384(00)00302-4

57. West DB, Fey D, Woods SC. Cholecystokinin persistently suppresses meal size but not food intake in free-feeding rats. Am J Physiol (1984) 246:R77687. doi: 10.1152/ajpregu.1984.246.5.R776

58. Eiden S, Daniel C, Steinbrueck A, Schmidt I, Simon E. Salmon calcitonin - a potent inhibitor of food intake in states of impaired leptin signalling in laboratory rodents. J Physiol (Lond) (2002) 541:1041-8. doi: 10.1113/ jphysiol.2002.018671

59. Osto M, Wielinga PY, Alder B, Walser N, Lutz TA. Modulation of the satiating effect of amylin by central ghrelin, leptin and insulin. Physiol Behav (2007) 91:566-72. doi: 10.1016/j.physbeh.2007.03.017

60. Roth JD, Roland BL, Cole RL, Trevaskis JL, Weyer C, Koda JE, et al. Leptin responsiveness restored by amylin agonism in diet-induced obesity: Evidence from nonclinical and clinical studies. Proc Natl Acad Sci USA (2008) 105:7257-62. doi: 10.1073/pnas.0706473105

61. Boyle CN, Rossier MM, Lutz TA. Influence of high-fat feeding, diet-induced obesity, and hyperamylinemia on the sensitivity to acute amylin. Physiol Behav (2011) 104:20-8. doi: 10.1016/j.physbeh.2011.04.044

62. Westermark P, Wernstedt C, Wilander E, Sletten K. A novel peptide in the calcitonin gene related peptide family as an amyloid fibril protein in the 
endocrine pancreas. Biochem Biophys Res Commun (1986) 140:827-31. doi: 10.1016/0006-291X(86)90708-4

63. Bretherton-Watt D, Gilbey SG, Ghatei MA, Beacham J, Macrae AD, Bloom SR. Very high concentrations of islet amyloid polypeptide are necessary to alter the insulin response to intravenous glucose in man. J Clin Endocrinol Metab (1992) 74:1032-5. doi: 10.1210/jcem.74.5.1569151

64. Bretherton-Watt D, Gilbey SG, Ghatei MA, Beacham J, Bloom SR. Failure to establish islet amyloid polypeptide (amylin) as a circulating beta cell inhibiting hormone in man. Diabetologia (1990) 33:115-7. doi: 10.1007/BF00401050

65. Ludvik B, Lell B, Hartter E, Schnack C, Prager R. Decrease of stimulated amylin release precedes impairment of insulin secretion in type II diabetes. Diabetes (1991) 40:1615-9. doi: 10.2337/diab.40.12.1615

66. Enoki S, Mitsukawa T, Takemura J, Nakazato M, Aburaya J, Toshimori H, et al. Plasma islet amyloid polypeptide levels in obesity, impaired glucose tolerance and non-insulin-dependent diabetes mellitus. Diabetes Res Clin Pract (1992) 15:97-102. doi: 10.1016/0168-8227(92)90074-2

67. Hanabusa T, Kubo K, Oki C, Nakano Y, Okai K, Sanke T, et al. Islet amyloid polypeptide (IAPP) secretion from islet cells and its plasma concentration in patients with non-insulin-dependent diabetes mellitus. Diabetes Res Clin Pract (1992) 15:89-96. doi: 10.1016/0168-8227(92)90073-Z

68. Blackard WG, Clore JN, Kellum JM. Amylin/insulin secretory ratios in morbidly obese man: inverse relationship with glucose disappearance rate. J Clin Endocrinol Metab (1994) 78:1257-60. doi: 10.1210/jcem.78.5.8175987

69. Kautzky-Willer A, Thomaseth K, Pacini G, Clodi M, Ludvik B, Streli C, et al. Role of islet amyloid polypeptide secretion in insulin-resistant humans. Diabetologia (1994) 37:188. doi: 10.1007/s001250050092

70. Roth CL, Bongiovanni KD, Gohlke B, Woelfle J. Changes in Dynamic Insulin and Gastrointestinal Hormone Secretion in Obese Children. J Pediatr Endocrinol Metab (2010) 23:1299-309. doi: 10.1515/jpem. 2010.204

71. Lee HJ, Choe YH, Lee JH, Sohn YB, Kim SJ, Park SW, et al. Delayed Response of Amylin Levels after an Oral Glucose Challenge in Children with Prader-Willi Syndrome. Yonsei Med J (2011) 52:257-62. doi: 10.3349/ymj. 2011.52.2.257

72. Jacobsen SH, Olesen SC, Dirksen C, Jørgensen NB, Bojsen-Møller KN, Kielgast U, et al. Changes in Gastrointestinal Hormone Responses, Insulin Sensitivity, and Beta-Cell Function Within 2 Weeks After Gastric Bypass in Non-diabetic Subjects. OBES Surg (2012) 22:1084-96. doi: 10.1007/s11695012-0621-4

73. Beglinger S, Meyer-Gerspach AC, Graf S, Zumsteg U, Drewe J, Beglinger C, et al. Effect of a test meal on meal responses of satiation hormones and their association to insulin resistance in obese adolescents. Obesity (2014) 22:2047-52. doi: 10.1002/oby.20805

74. Klementova M, Thieme L, Haluzik M, Pavlovicova R, Hill M, Pelikanova T, et al. A Plant-Based Meal Increases Gastrointestinal Hormones and Satiety More Than an Energy- and Macronutrient-Matched Processed-Meat Meal in T2D, Obese, and Healthy Men: A Three-Group Randomized Crossover Study. Nutrients (2019) 11(1):157. doi: 10.3390/nu11010157

75. Roberts CK, Izadpanah A, Angadi SS, Barnard RJ. Effects of an intensive short-term diet and exercise intervention: comparison between normalweight and obese children. Am J Physiol Regul Integr Comp Physiol (2013) 305:R552-7. doi: 10.1152/ajpregu.00131.2013

76. Pieber TR, Roitelman J, Lee Y, Luskey KL, Stein DT. Direct plasma radioimmunoassay for rat amylin-(1-37): concentrations with acquired and genetic obesity. Am J Physiol Endocrinol Metab (1994) 267:E156-64. doi: 10.1152/ajpendo.1994.267.1.E156

77. Boyle CN, Lutz TA. Amylinergic control of food intake in lean and obese rodents. Physiol Behav (2011) 105:129-37. doi: 10.1016/j.physbeh.2011.02.015

78. Ardaillou R. Kidney and calcitonin. Nephron (1975) 15:250-60. doi: 10.1159/ 000180515

79. Davey RA, Findlay DM. Calcitonin: Physiology or fantasy? J Bone Mineral Res (2013) 28:973-9. doi: 10.1002/jbmr.1869

80. Austin LA, Heath H, Go VLW. Regulation of Calcitonin Secretion in Normal Man by Changes of Serum Calcium within the Physiologic Range. J Clin Invest (1979) 64:1721-4. doi: 10.1172/JCI109636

81. Copp DH, Cameron EC, Cheney BA, Davidson AG, Henze KG. Evidence for calcitonin-a new hormone from the parathyroid that lowers blood calcium. Endocrinology (1962) 70:638-49. doi: 10.1210/endo-70-5-638
82. Hurley DL, Tiegs RD, Wahner HW, Heath HI. Axial and Appendicular Bone Mineral Density in Patients with Long-Term Deficiency or Excess of Calcitonin. N Engl J Med (1987) 317:537-41. doi: 10.1056/NEJM198708273170904

83. Downs RW Jr., Bell NH, Ettinger MP, Walsh BW, Favus MJ, Mako B, et al. Comparison of Alendronate and Intranasal Calcitonin for Treatment of Osteoporosis in Postmenopausal Women. J Clin Endocrinol Metab (2000) 85:1783-8. doi: 10.1210/jcem.85.5.6606

84. Lutz TA, Tschudy S, Rushing PA, Scharrer E. Amylin receptors mediate the anorectic action of salmon calcitonin (sCT). Peptides (2000) 21:233-8. doi: 10.1016/S0196-9781(99)00208-9

85. Sgambato S, Passariello N, Paolisso G, Marano A, Buoninconti R, Tesauro P. Effect of human calcitonin (hCT) on glucose- and arginine-stimulated insulin secretion. Acta Diabetes lat (1986) 23:13-22. doi: 10.1007/BF02581349

86. Giugliano D, Passariello N, Sgambato S, Torella R, D’Onofrio F. Calcitonin modulation of insulin and glucagon secretion in man. Am J Physiol Endocrinol Metab (1982) 242:E206-13. doi: 10.1152/ajpendo.1982.242.3.E206

87. Ziegler R, Bellwinkel S, Schmidtchen D, Minne H. Effects of hypercalcemia, hypercalcemia and calcitonin on glucose stimulated insulin secretion in man. Horm Metab Res (1972) 4:60. doi: 10.1055/s-0028-1097084

88. Polymeris A, Papapetrou P, Papandroulaki F, Thanou S. Hyperinsulinemia during oral glucose tolerance test and high normal serum cortisol are associated with increased secretion of calcitonin in normal subjects. HORMONES (2011) 10:304-12. doi: 10.14310/horm.2002.1322

89. Care AD, Abbas SK, Pell J, Seitz PK, Cooper CW. Stimulatory Effect of Insulin on Calcitonin Secretion. Horm Metab Res (1998) 30:200-5. doi: 10.1055/s-2007-978866

90. Shiraki M, Ito H, Fujimaki H, Higuchi T. Relation between Body Size and Bone Mineral Density with special reference to Sex Hormones and Calcium Regulating Hormones in Elderly Females. Endocrinol Japonica (1991) 38:343-9. doi: 10.1507/endocrj1954.38.343

91. Abbasi A, Corpeleijn E, Postmus D, Gansevoort RT, de Jong PE, Gans ROB, et al. Plasma Procalcitonin Is Associated with Obesity, Insulin Resistance, and the Metabolic Syndrome. J Clin Endocrinol Metab (2010) 95:E26-31. doi: 10.1210/jc.2010-0305

92. Ryan G, Briscoe TA, Jobe L. Review of pramlintide as adjunctive therapy in treatment of type 1 and type 2 diabetes. Drug Des Devel Ther (2009) 2:20314. doi: 10.2147/DDDT.S3225

93. Colburn WA, Gottlieb AB, Koda J, Kolterman OG. Pharmacokinetics and Pharmacodynamics of AC137 (25,28,29 Tripro-Amylin, Human) After Intravenous Bolus and Infusion Doses in Patients with Insulin-Dependent Diabetes. J Clin Pharmacol (1996) 36:13-24. doi: 10.1002/j.15524604.1996.tb04147.x

94. Smith SR, Blundell JE, Burns C, Ellero C, Schroeder BE, Kesty NC, et al. Pramlintide treatment reduces $24-\mathrm{h}$ caloric intake and meal sizes and improves control of eating in obese subjects: a 6-wk translational research study. Am J Physiol Endocrinol Metab (2007) 293:E620-7. doi: 10.1152/ ajpendo.00217.2007

95. Aronne L, Fujioka K, Aroda V, Chen K, Halseth A, Kesty NC, et al. Progressive reduction in body weight after treatment with the amylin analog pramlintide in obese subjects: a phase 2, randomized, placebocontrolled, dose-escalation study. J Clin Endocrinol Metab (2007) 92:297783. doi: $10.1210 /$ jc. $2006-2003$

96. Smith SR, Aronne LJ, Burns CM, Kesty NC, Halseth AE, Weyer C. Sustained Weight Loss Following 12-Month Pramlintide Treatment as an Adjunct to Lifestyle Intervention in Obesity. Diabetes Care (2008) 31:1816-23. doi: $10.2337 / \mathrm{dc} 08-0029$

97. Foster GD, Wyatt HR, Hill JO, Makris AP, Rosenbaum DL, Brill C, et al. Weight and Metabolic Outcomes After 2 Years on a Low-Carbohydrate Versus Low-Fat Diet. Ann Internal Med (2010) 153:147-57. doi: 10.7326/ 0003-4819-153-3-201008030-00005

98. Hollander P, Maggs DG, Ruggles JA, Fineman M, Shen L, Kolterman OG, et al. Effect of Pramlintide on Weight in Overweight and Obese Insulin-Treated Type 2 Diabetes Patients. Obes Res (2004) 12:661-8. doi: 10.1038/oby.2004.76

99. Hollander PA, Levy P, Fineman MS, Maggs DG, Shen LZ, Strobel SA, et al. Pramlintide as an Adjunct to Insulin Therapy Improves Long-Term Glycemic and Weight Control in Patients With Type 2 Diabetes: A 1-year randomized controlled trial. Diabetes Care (2003) 26:784-90. doi: 10.2337/ diacare.26.3.784 
100. Karl D, Philis-Tsimikas A, Darsow T, Lorenzi G, Kellmeyer T, Lutz K, et al. Pramlintide as An Adjunct to Insulin in Patients with Type 2 Diabetes in A Clinical Practice Setting Reduced A1C, Postprandial Glucose Excursions, And Weight. Diabetes Technol Ther (2007) 9:191-9. doi: 10.1089/dia.2006.0013

101. Maggs D, Shen L, Strobel S, Brown D, Kolterman O, Weyer C. Effect of pramlintide on $\mathrm{A} 1 \mathrm{C}$ and body weight in insulin-treated African Americans and Hispanics with type 2 diabetes: a pooled post hoc analysis. Metabolism (2003) 52:1638-42. doi: 10.1016/j.metabol.2003.06.003

102. Ratner RE, Want LL, Fineman MS, Velte MJ, Ruggles JA, Gottlieb A, et al. Adjunctive Therapy with the Amylin Analogue Pramlintide Leads to a Combined Improvement in Glycemic and Weight Control in InsulinTreated Subjects with Type 2 Diabetes. Diabetes Technol Ther (2002) 4:5161. doi: 10.1089/15209150252924094

103. Riddle M, Frias J, Zhang B, Maier H, Brown C, Lutz K, et al. Pramlintide Improved Glycemic Control and Reduced Weight in Patients With Type 2 Diabetes Using Basal Insulin. Diabetes Care (2007) 30:2794-9. doi: 10.2337/dc070589

104. Thompson RG, Pearson L, Schoenfeld SL, Kolterman OG. Pramlintide, a synthetic analog of human amylin, improves the metabolic profile of patients with type 2 diabetes using insulin. The Pramlintide in Type 2 Diabetes Group. Diabetes Care (1998) 21:987-93. doi: 10.2337/diacare.21.6.987

105. Fineman M, Bahner A, Gottlieb A, Kolterman OG. Effects Of Six Months Administration Of Pramlintide As An Adjunct To Insulin Therapy On Metabolic Control In People With Type 1 Diabetes. Diabetes (1999) 48: SA113-3.

106. Ratner RE, Dickey R, Fineman M, Maggs DG, Shen L, Strobel SA, et al. Amylin replacement with pramlintide as an adjunct to insulin therapy improves long-term glycaemic and weight control in Type 1 diabetes mellitus: a 1-year, randomized controlled trial. Diabetic Med (2004) 21:1204-12. doi: 10.1111/j.1464-5491.2004.01319.x

107. Huffman DM, McLean GW, Seagrove MA. Continuous subcutaneous pramlintide infusion therapy in patients with type 1 diabetes: observations from a pilot study. Endocr Pract (2009) 15:689-95. doi: 10.4158/EP09044.ORR1

108. King A. Minimal Reduction in Insulin Dosage with Pramlintide Therapy when Pretreatment Near-Normal Glycemia is Established and Square-Wave Meal Bolus is Used. Endocrine Pract (2009) 15:229-33. doi: 10.4158/ EP.15.3.229

109. Kishiyama CM, Burdick PL, Cobry EC, Gage VL, Messer LH, McFann K. Chase HP. A Pilot Trial of Pramlintide Home Usage in Adolescents With Type 1 Diabetes. Pediatrics (2009) 124:1344-7. doi: 10.1542/peds.2008-3750

110. Ratner R, Whitehouse F, Fineman MS, Strobel S, Shen L, Maggs DG, et al. Adjunctive Therapy with Pramlintide Lowers HbAlc without Concomitant Weight Gain and Increased Risk of Severe Hypoglycemia in Patients with Type 1 Diabetes Approaching Glycemic Targets. Exp Clin Endocrinol Diabetes (2005) 113:199-204. doi: 10.1055/s-2005-837662

111. Sherr JL, Patel NS, Michaud CI, Palau-Collazo MM, Van Name MA, Tamborlane WV, et al. Mitigating Meal-Related Glycemic Excursions in an Insulin-Sparing Manner During Closed-Loop Insulin Delivery: The Beneficial Effects of Adjunctive Pramlintide and Liraglutide. Diabetes Care (2016) 39:1127-34. doi: 10.2337/dc16-0089

112. Whitehouse F, Kruger DF, Fineman M, Shen L, Ruggles JA, Maggs DG, et al. Kolterman OG. A Randomized Study and Open-Label Extension Evaluating the Long-Term Efficacy of Pramlintide as an Adjunct to Insulin Therapy in Type 1 Diabetes. Diabetes Care (2002) 25:724-30. doi: 10.2337/ diacare.25.4.724

113. Wadden Thomas A, Webb Victoria L, Moran Caroline H, Bailer Brooke A. Lifestyle Modification for Obesity. Circulation (2012) 125:1157-70. doi: 10.1161/CIRCULATIONAHA.111.039453

114. Bray GA, Chatellier A, Duncan C, Greenway FL, Levy E, Ryan DH, et al. Diabetes Prevention Program Research Group. 10-year follow-up of diabetes incidence and weight loss in the Diabetes Prevention Program Outcomes Study. Lancet (2009) 374:1677-86. doi: 10.1016/S0140-6736(09)61457-4

115. Pi-Sunyer X, Astrup A, Fujioka K, Greenway F, Halpern A, Krempf M, et al. A Randomized, Controlled Trial of $3.0 \mathrm{mg}$ of Liraglutide in Weight Management. New Engl J Med (2015) 373:11-22. doi: 10.1056/NEJMoa 1411892

116. Salminen P, Helmiö M, Ovaska J, Juuti A, Leivonen M, Peromaa-Haavisto P, et al. Effect of Laparoscopic Sleeve Gastrectomy vs Laparoscopic Roux-en-Y
Gastric Bypass on Weight Loss at 5 Years Among Patients With Morbid Obesity: The SLEEVEPASS Randomized Clinical Trial. JAMA (2018) 319:241-54. doi: 10.1001/jama.2017.20313

117. Tschöp MH, Finan B, Clemmensen C, Gelfanov V, Perez-Tilve D, Müller TD, et al. Unimolecular Polypharmacy for Treatment of Diabetes and Obesity. Cell Metab (2016) 24:51-62. doi: 10.1016/j.cmet.2016.06.021

118. Roth JD, Coffey T, Jodka CM, Maier H, Athanacio JR, Mack CM, et al. Combination Therapy with Amylin and Peptide YY[3-36] in Obese Rodents: Anorexigenic Synergy and Weight Loss Additivity. Endocrinology (2007) 148:6054-61. doi: 10.1210/en.2007-0898

119. Roth JD, D’Souza L, Griffin PS, Athanacio J, Trevaskis JL, Nazarbaghi R, et al. Interactions of amylinergic and melanocortinergic systems in the control of food intake and body weight in rodents. Diabetes Obes Metab (2012) 14:60815. doi: 10.1111/j.1463-1326.2012.01570.x

120. Aronne LJ, Halseth AE, Burns CM, Miller S, Shen LZ. Enhanced Weight Loss Following Coadministration of Pramlintide With Sibutramine or Phentermine in a Multicenter Trial. Obesity (2010) 18:1739-46. doi: 10.1038/oby.2009.478

121. Ravussin E, Smith SR, Mitchell JA, Shringarpure R, Shan K, Maier H, et al. Enhanced Weight Loss With Pramlintide/Metreleptin: An Integrated Neurohormonal Approach to Obesity Pharmacotherapy. Obes (Silver Spring) (2009) 17:1736-43. doi: 10.1038/oby.2009.184

122. Bello NT, Kemm MH, Ofeldt EM, Moran TH. Dose combinations of exendin-4 and salmon calcitonin produce additive and synergistic reductions in food intake in nonhuman primates. Am J Physiol Regul Integr Comp Physiol (2010) 299:R945-52. doi: 10.1152/ajpregu.00275.2010

123. Liberini CG, Koch-Laskowski K, Shaulson E, McGrath LE, Lipsky RK, Lhamo R, et al. Combined Amylin/GLP-1 pharmacotherapy to promote and sustain long-lasting weight loss. Sci Rep (2019) 9:1-11. doi: 10.1038/ s41598-019-44591-8

124. Novo Nordisk A/S. Investigation of Safety, Tolerability, Pharmacokinetics and Pharmacodynamics of Multiple Dosing of NNC0174-0833 in Combination With Semaglutide in Subjects Being Overweight or With Obesity (2020). Available at: https://clinicaltrials.gov/ct2/show/ NCT03600480 (Accessed August 25, 2020).

125. Mack CM, Soares CJ, Wilson JK, Athanacio JR, Turek VF, Trevaskis JL, et al. Davalintide (AC2307), a novel amylin-mimetic peptide: enhanced pharmacological properties over native amylin to reduce food intake and body weight. Int J Obes (2010) 34:385-95. doi: 10.1038/ijo.2009.238

126. Mack CM, Smith PA, Athanacio JR, Xu K, Wilson JK, Reynolds JM, et al. Glucoregulatory effects and prolonged duration of action of davalintide: a novel amylinomimetic peptide. Diabetes Obes Metab (2011) 13:1105-13. doi: 10.1111/j.1463-1326.2011.01465.x

127. Hilton J, Dowton M, Houssami S, Sexton P. Identification of key components in the irreversibility of salmon calcitonin binding to calcitonin receptors. J Endocrinol (2000) 166:213-26. doi: 10.1677/joe.0.1660213

128. Zakariassen HL, John LM, Lutz TA. Central control of energy balance by amylin and calcitonin receptor agonists and their potential for treatment of metabolic diseases. Basic Clin Pharmacol Toxicol (2020) 127:163-77. doi: $10.1111 /$ bcpt.13427

129. Guerreiro LH, Guterres MFAN, Melo-Ferreira B, Erthal LCS, Rosa M da S, Lourenço D, et al. Preparation and characterization of PEGylated amylin. AAPS PharmSciTech (2013) 14:1083-97. doi: 10.1208/s12249-013-9987-4

130. Guterres MFAN, Guerreiro LH, Melo-Ferreira B, Erthal LCS, Lima LMTR Amylin conjugation with methoxyl polyethyleneglycol. Protein Pept Lett (2013) 20:1264-71. doi: 10.2174/09298665113209990067

131. Kowalczyk R, Brimble MA, Tomabechi Y, Fairbanks AJ, Fletcher M, Hay DL. Convergent chemoenzymatic synthesis of a library of glycosylated analogues of pramlintide: structure-activity relationships for amylin receptor agonism. Org Biomol Chem (2014) 12:8142-51. doi: 10.1039/c4ob01208a

132. Nascimento CVMF, Sinezia C, Sisnande T, Lima LMTR, Lacativa PGS. BZ043, a novel long-acting amylin analog, reduces gastric emptying, food intake, glycemia and insulin requirement in streptozotocin-induced diabetic rats. Peptides (2019) 114:44-9. doi: 10.1016/j.peptides.2019.04.004

133. Tomabechi Y, Krippner G, Rendle PM, Squire MA, Fairbanks AJ. Glycosylation of pramlintide: synthetic glycopeptides that display in vitro and in vivo activities as amylin receptor agonists. Chemistry (2013) 19:15084-8. doi: 10.1002/chem.201303303 
134. Yule LR, Bower RL, Kaur H, Kowalczyk R, Hay DL, Brimble MA. Synthesis and amylin receptor activity of glycomimetics of pramlintide using click chemistry. Org Biomol Chem (2016) 14:5238-45. doi: 10.1039/c6ob00850j

135. Dahl K, SCHÄFFER L, Kruse T. Human amylin analogues (2013). Available at: https://patents.google.com/patent/WO2013156594A1/en (Accessed August 27, 2020)

136. Brings A, Borghardt JM, Skarbaliene J, Baader-Pagler T, Deryabina MA, Rist W, et al. Modeling energy intake and body weight effects of a long-acting amylin analogue. J Pharmacokinet Pharmacodynamics (2018) 45:215-33. doi: 10.1007/ s10928-017-9557-6

137. Kalafateli AL, Vestlund J, Raun K, Egecioglu E, Jerlhag E. Effects of a selective long-acting amylin receptor agonist on alcohol consumption, food intake and body weight in male and female rats. Addict Biol (2020) e12910. doi: $10.1111 / \mathrm{adb} .12910$

138. Novo Nordisk A/S. Investigation of Pharmacokinetic Properties, Safety and Tolerability of Single Subcutaneous Doses of NNC0174-0833 in Male Japanese and Caucasian Subjects Being Normal Weight, Overweight or With Obesity (2019). Available at: https://clinicaltrials.gov/ct2/show/ NCT03787225 (Accessed August 25, 2020).

139. Novo Nordisk A/S. Investigation of Safety and Efficacy of NNC0174-0833 for Weight Management - a Dose Finding Trial (2020). Available at: https:// clinicaltrials.gov/ct2/show/NCT03856047 (Accessed August 25, 2020).

140. Lau DCW, McFarlane J, Erichsen L, Fransisco AM, Le Roux C, McGowan B, et al. Efficacy and Safety of AM833 for Weight Loss: A Dose-finding Trial in Adults With Overweight/Obesity. Oral 043. Available at: https://tos.planion. com/Web.User/AbstractDet?ACCOUNT $=$ TOS \&ABSID $=23842 \& C O N F=$ OW2020\&ssoOverride=OFF\&CKEY (Accessed November 16, 2020).

141. A/S NN. Novo Nordisk successfully completes AM833 phase 2 trial and phase 1 combination trial with AM833 and semaglutide in obesity (2020). Available at: http://www.globenewswire.com/news-release/2020/06/18/ 2050266/0/en/Novo-Nordisk-successfully-completes-AM833-phase-2-trialand-phase-1-combination-trial-with-AM833-and-semaglutide-in-obesity. html (Accessed October 5, 2020).

142. Skarbaliene J, Just R. Anti-diabetic effects of novel long-acting amylin analogues ZP4982 and ZP5461 in ZDF rats.1. New Orleans: American Diabetes Association's (ADA) 76th Scientific Sessions. Available at: https:// www.zealandpharma.com/publications-amylin.

143. Skarbaliene J, Pagler T, Eickelmann P, Just R. Anti-obesity effects of the novel long-acting amylin analogue ZP4982 in high-fat diet fed rats.1. New Orleans: American Diabetes Association's (ADA) 76th Scientific Sessions. Available at: https://www.zealandpharma.com/publications-amylin.

144. Boehringer Ingelheim. Safety, Tolerability, Pharmacokinetics and Pharmacodynamics of Single Rising Subcutaneous Doses of BI 473494 in Healthy Male Subjects (Single-blind, Partially Randomised, Placebocontrolled Parallel Group Design) (2018). Available at: https:// clinicaltrials.gov/ct2/show/NCT03195088 (Accessed August 25, 2020).

145. Pharma Z. Zealand Pharma regains worldwide rights to Amylin analog program from Boehringer Ingelheim (2020). Available at: http://www. globenewswire.com/news-release/2020/03/20/2004337/0/en/ZealandPharma-regains-worldwide-rights-to-Amylin-analog-program-fromBoehringer-Ingelheim.html (Accessed August 27, 2020).

146. Galante L, Horton R, Joplin GF, Woodhouse NJY, MacIntyre I. Comparison of Human, Porcine and Salmon Synthetic Calcitonins in Man and the Rat. Clin Sci (1971) 40:9P.3-10P. doi: 10.1042/cs040009Pb

147. Jonderko G, Jonderko K, Gołab T. Effect of calcitonin on gastric emptying and on postprandial gastrin and insulin release in patients with type I gastric ulcer. Neth J Med (1990) 37:11-6. doi: 10.1136/ gut.30.4.430

148. Jonderko K, Końca A, Gołab T, Jonderko G. Effect of calcitonin on gallbladder volume in man. J Gastroenterol Hepatol (1989) 4:505-11. doi: 10.1111/j.1440-1746.1989.tb00854.x

149. Morley JE, Levine AS, Brown DM, Handwerger BS. The effect of calcitonin on food intake in diabetic mice. Peptides (1982) 3:17-20. doi: 10.1016/01969781(82)90135-8

150. Perlow MJ, Freed WJ, Carman JS, Wyatt RJ. Calcitonin reduces feeding in man, monkey and rat. Pharmacol Biochem Behav (1980) 12:609-12. doi: 10.1016/0091-3057(80)90196-3

151. Feigh M, Henriksen K, Andreassen KV, Hansen C, Henriksen JE, BeckNielsen $\mathrm{H}$, et al. A novel oral form of salmon calcitonin improves glucose homeostasis and reduces body weight in diet-induced obese rats. Diabetes Obes Metab (2011) 13:911-20. doi: 10.1111/j.1463-1326.2011.01425.x

152. Feigh M, Hjuler ST, Andreassen KV, Gydesen S, Ottosen I, Henriksen JE, et al. Oral salmon calcitonin enhances insulin action and glucose metabolism in diet-induced obese streptozotocin-diabetic rats. Eur J Pharmacol (2014) 737:91-6. doi: 10.1016/j.ejphar.2014.05.016

153. Wielinga PY, Alder B, Lutz TA. The acute effect of amylin and salmon calcitonin on energy expenditure. Physiol Behav (2007) 91:212-7. doi: 10.1016/j.physbeh.2007.02.012

154. Tilakaratne N, Christopoulos G, Zumpe ET, Foord SM, Sexton PM. Amylin Receptor Phenotypes Derived from Human Calcitonin Receptor/ RAMP Coexpression Exhibit Pharmacological Differences Dependent on Receptor Isoform and Host Cell Environment. I Pharmacol Exp Ther (2000) 294:61-72.

155. Larsen AT, Sonne N, Andreassen KV, Karsdal MA, Henriksen K. The Calcitonin Receptor Plays a Major Role in Glucose Regulation as a Function of Dual Amylin and Calcitonin Receptor Agonist Therapy. J Pharmacol Exp Ther (2020) 374:74-83. doi: 10.1124/jpet.119.263392

156. Study to Evaluate the Efficacy and Safety of KBP-042 in Patients With Type 2 Diabetes - Full Text View - ClinicalTrials.gov. Available at: https:// clinicaltrials.gov/ct2/show/NCT03230786 (Accessed August 28, 2020).

157. Lilly cuts a trio of pipeline assets, including BTK inhibitor, diabetes drug. Available at: https://www.fiercebiotech.com/biotech/lilly-cuts-a-triopipeline-assets-including-btk-inhibitor-diabetes-med (Accessed August 28, 2020).

158. Danish biotech boss after shelved Lilly project: "We have better molecules." Available at: https://medwatch.dk/Top_picks_in_english/article11178874. ece (Accessed August 28, 2020).

159. A Clinical Study to Evaluate the Safety, Tolerability, PK, PD, and Efficacy of KBP-089 in Patients With T2DM - Full Text View - ClinicalTrials.gov. Available at: https://clinicaltrials.gov/ct2/show/NCT03907202 (Accessed August 28, 2020).

Conflict of Interest: The authors declare that the research was conducted in the absence of any commercial or financial relationships that could be construed as a potential conflict of interest.

Copyright (c) 2021 Mathiesen, Lund, Vilsbøll, Knop and Bagger. This is an open-access article distributed under the terms of the Creative Commons Attribution License (CC BY). The use, distribution or reproduction in other forums is permitted, provided the original author(s) and the copyright owner(s) are credited and that the original publication in this journal is cited, in accordance with accepted academic practice. No use, distribution or reproduction is permitted which does not comply with these terms. 